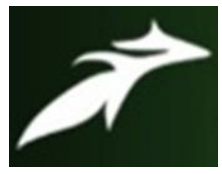

Sunil Birle et al, International Journal of Advances in Agricultural Science and Technology,

Vol.8 Issue.8, August-2021, pg. 115-120

ISSN: 2348-1358

Impact Factor: 6.057

NAAS Rating: 3.77

\title{
A Study on Decision Making Ability and Participation in Various Agriculture Activities Performed by Farm Women in Khargone District of M.P
}

\author{
${ }^{1}$ Mr. Sunil Birle; ${ }^{2}$ Dr. Sandhya Choudhary; ${ }^{3}$ Dr. Dhavendra Singh; ${ }^{4}$ Dr. S.K. Choudhary \\ ${ }^{1}$ M.Sc. Student, Agriculture Extension \&Communication, CoA, Indore \\ ${ }^{2}$ Professor and Head KVK, Manawar, (M.P.) \\ ${ }^{3}$ Senior Scientist (Agronomy), KVK, Manawar, (M.P.) \\ ${ }^{4}$ Chief Scientist, (Agronomy) D.A, R.P. CoA, Indore \\ DOI: 10.47856/ijaast.2021.v08i8.013
}

\begin{abstract}
The role of women has always been a multi-dimensional and significant as women have performed well in case of agricultural activities, domestic activities, marketing activities as far as labour requirement is considered. The decision-making process is an important segment of every household because the functioning of family resource management depends on the efficiency of decision-making progress. So, women involvement in decision-making process has been of great importance because sampling method to make a sample of 120 respondents. Hence finally the sampling consisted of 120 respondents. More number of farm women were found to have level of decision making process: the highest decision making behavior in sowing followed by winnowing process, seed processing, irrigation management, collection of harvested crop, storage, field preparation, selection of seed/variety, marketing, Manures and fertilizer application, weeding, harvesting, seed treatment, Pest and disease management and soil testing.
\end{abstract}

\section{Introduction -}

Decision-making and accurate performance of all activities helps in making an enterprise more viable, feasible and profitable. Before performing any operation task a person thinks over various options available to him/her and selects only those which are simple, profitable, compatible and relatively better. If a person before implementing a task also plans and decides about various activities, can produce excellent results.

But in case of agriculture, due to gender bias, farm women, a significant contributor in various activities is being kept away from the role of decision maker.

Women contribute a major share to the farm labour, all over the world, especially in the developing countries like India. According to the 2011 census, the percentage share of farmers and agricultural labourers in the rural population of India are 34 percent and 41.4 per cent respectively in which the share of women cultivators and women agricultural labourers are 10.3 per cent and 17.7 per cent, respectively. 


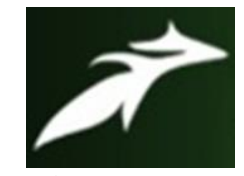

Sunil Birle et al, International Journal of Advances in Agricultural Science and Technology, Vol.8 Issue.8, August-2021, pg. 115-120

ISSN: 2348-1358

Impact Factor: 6.057

NAAS Rating: 3.77

The role of farm women in decision making process in agriculture in Madhya Pradesh has not been explored by many researchers. To examine the role of farm women in the decision making process in growing of crop in agriculture, different areas of decision making were identified for the present study, considering their importance for agricultural development.

\section{Objective-}

To measure the decision making ability of farm women and their participation in various agriculture activities.

\section{Review of Literature-}

Chayal et al. (2013) also found that decisions on cropping pattern and marketing of produce were made solely by men. Although, decision making score was higher among the man respondents, woman respondents participated in decision making processes in the areas of crop and variety to be sown, sale of farm products and savings.

Godara and Varsha (2017) found that majority of the respondent has not involved in decision related to purchase and sale of land. Only near about 29.7 per cent respondents were partially involved in taking decision in this activity.

Dudi and Meena (2017) revealed that the farm women participated in decision making process in each and every farm activities. The data indicated that the higher number of farm women $(57.11 \%)$ were observed in low category of decision making followed by medium category of decision making with (27.74\%) and high category of decision making (15.15\%) also found that the more number of farm women in agricultural activities taken low decision making involvement.

Patel et al. (2017) indicate that 84 per cent and 75.50per cent of the farm women took participation in decision about choosing the type and breed of milch animals, respectively. However, majority of them $(71.50 \%$ and $67 \%)$ of the farm women did not participation in decision about taking loan for purchase of milch animals and purchase of feed and fodder, respectively.

\section{Methodology-}

There are nine blocks in Khargone district. Namely- Barwaha, Bhagwanpura, Bhikangaon, Goganwa, Kasarawad, Maheshwar, Segoan, Zirnya, Khargone. Out of these only one block i.e. Kasarawad will be selected purposively for present study. A list of all the villages of the selected block will be and taken 


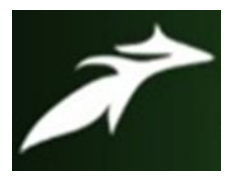

Sunil Birle et al, International Journal of Advances in Agricultural Science and Technology, Vol.8 Issue.8, August-2021, pg. 115-120

ISSN: 2348-1358

Impact Factor: 6.057

NAAS Rating: 3.77

from block office out of them one block will be selected purposively i.e. Kasarawad. Kasrawad block comprises of 220 villages, Out of these 6 villages will be selected randomly for the ongoing study.

\section{Selection of the respondents-}

In Kasrawad block, the majority of the women have been found to be involved in agriculture activities viz, Vegetable production, Masala processing, Vermiculture, Goatry and Dairy enterprise for their livelihood. From this block six villages were selected for the study, and prepared of the list of respondents on the basis of higher number of rural farm women members. This list of farm women were selected through proportionater and of sampling method to make a sample of 120 respondents. Hence finally the sampling consisted of 120 respondents.

\section{Decision making ability of farm women and their participation-}

The decision making ability of a farm women is operationally defined as the degree of weighing the available alternatives in terms of their desirability and their likelihoods and choosing the most appropriate one for achieving maximum profit on his farming. The scale developed by Supe (1969), and as adopted by Nagesh (2006) with suitable modifications was used.

\section{Result and Discussion-}

Measure the decision making ability of farm women and their participation in various agriculture activities.

Table: Measure the decision making ability of farm women

\begin{tabular}{|l|l|l|l|l|l|}
\hline \multicolumn{2}{|l|}{$\begin{array}{l}\text { S. } \\
\text { No. }\end{array}$} & \multirow{2}{*}{ Agriculture activities } & \multicolumn{2}{c}{ Decision making ability } & \multirow{2}{*}{$\begin{array}{c}\text { Mean } \\
\text { score }\end{array}$} \\
\cline { 3 - 6 } & & Low & Medium & High & \\
\hline 1. & Field preparation & 69 & 29 & 22 & 1.60 \\
\hline 2. & Selection of variety / seed & 73 & 24 & 23 & 1.58 \\
\hline 3. & Sowing Methods & 35 & 53 & 32 & 1.97 \\
\hline 4. & Weeding & 61 & 32 & 20 & 1.54 \\
\hline 5. & Soil testing & 79 & 27 & 14 & 1.44 \\
\hline
\end{tabular}




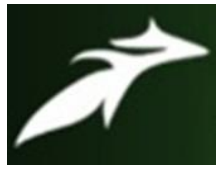

Sunil Birle et al, International Journal of Advances in Agricultural Science and Technology, Vol.8 Issue.8, August-2021, pg. 115-120

ISSN: 2348-1358

Impact Factor: 6.057

NAAS Rating: 3.77

\begin{tabular}{|l|l|l|l|l|l|}
\hline 6. & Seed treatment & 73 & 35 & 12 & 1.49 \\
\hline 7. & Irrigation management & 65 & 23 & 32 & 1.72 \\
\hline 8. & Manures and fertilizer application & 71 & 32 & 17 & 1.55 \\
\hline 9. & Pest and disease management & 83 & 19 & 18 & 1.45 \\
\hline 10. & Harvesting & 79 & 21 & 20 & 1.50 \\
\hline 11. & Collection of harvested crop & 63 & 31 & 26 & 1.69 \\
\hline 12. & Winnowing process & 55 & 22 & 43 & 1.90 \\
\hline 13. & Seed processing & 38 & 59 & 23 & 1.87 \\
\hline 14 & Storage & 57 & 44 & 19 & 1.68 \\
\hline 15 & Marketing & 74 & 23 & 23 & 1.57 \\
\hline & Overall & $\mathbf{6 5}$ & $\mathbf{3 2}$ & $\mathbf{2 3}$ & $\mathbf{1 2 0}$ \\
\hline
\end{tabular}

Table: Measure the participation of farm women in various agriculture activities

$\mathbf{n = 1 2 0}$

\begin{tabular}{|c|l|l|l|l|l|}
\hline \multirow{2}{*}{ S.N. } & \multirow{2}{*}{ Agriculture activities } & \multicolumn{3}{|c|}{ Extent of participation } & \multirow{2}{*}{ Mean } \\
\cline { 3 - 5 } & & Low & medium & High & Score \\
\hline 1. & Field preparation & 35 & 43 & 42 & 2.05 \\
\hline 2. & Selection of variety / seed & 23 & 43 & 51 & 2.18 \\
\hline 3. & Sowing Methods & 49 & 38 & 33 & 1.86 \\
\hline 4. & Weeding & 26 & 53 & 41 & 2.12 \\
\hline 5. & Soil testing & 19 & 45 & 56 & 2.30 \\
\hline
\end{tabular}




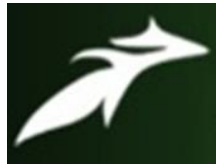

Sunil Birle et al, International Journal of Advances in Agricultural Science and Technology, Vol.8 Issue.8, August-2021, pg. 115-120

ISSN: 2348-1358

Impact Factor: 6.057

NAAS Rating: 3.77

\begin{tabular}{|c|l|l|l|l|l|}
\hline 6. & Seed treatment & 21 & 38 & 61 & 2.33 \\
\hline 7. & Irrigation management & 18 & 40 & 62 & 2.36 \\
\hline 8. & Manures and fertilizer application & 21 & 28 & 71 & 2.41 \\
\hline 9. & Pest and disease management & 29 & 18 & 73 & 2.36 \\
\hline 10. & Harvesting & 16 & 38 & 66 & 2.41 \\
\hline 11. & Collection of harvested crop & 29 & 26 & 65 & 2.30 \\
\hline 12. & Winnowing process & 12 & 32 & 76 & 2.53 \\
\hline 13. & Seed processing & 21 & 35 & 64 & 2.35 \\
\hline 14 & Storage & 29 & 31 & 60 & 2.25 \\
\hline 15 & Marketing & 23 & 35 & 62 & 2.32 \\
\hline
\end{tabular}

Table: measure the overall participation of farm women in various agriculture activities

$\mathrm{n}=\mathbf{1 2 0}$

\begin{tabular}{|c|c|c|c|}
\hline S. No. & Categories & $\begin{array}{c}\text { Number of } \\
\text { Respondents }\end{array}$ & Percentage \\
\hline 1. & Low & 25 & 20.83 \\
\hline 2. & Medium & 36 & 30.00 \\
\hline 3. & High & 59 & 49.17 \\
\hline & Total & 120 & 100 \\
\hline
\end{tabular}




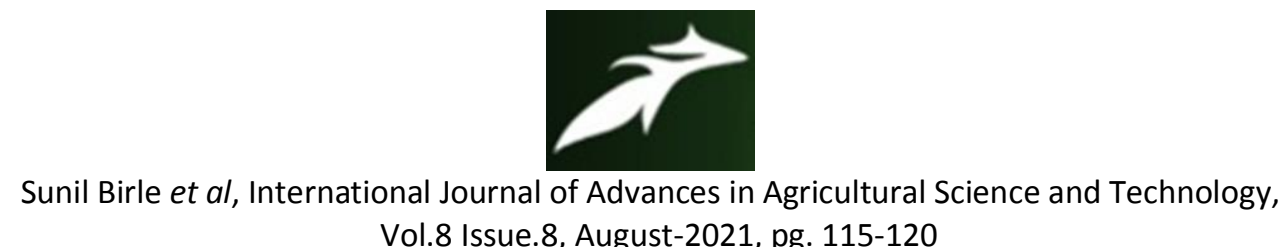

Vol.8 Issue.8, August-2021, pg. 115-120

ISSN: 2348-1358

Impact Factor: 6.057

NAAS Rating: 3.77

\section{Decision making ability of farm women and their participation in various agriculture activities:}

\section{Decision making ability of farm women}

More number of farm women were found to have level of decision making process: the highest decision making behavior in sowing because sowing process is easily handled by farm women followed by winnowing process because women is expert in this process, seed processing, irrigation management, collection of harvested crop, storage, field preparation, selection of seed/variety, marketing, Manures and fertilizer application, weeding, harvesting, seed treatment, Pest and disease management and soil testing.

\section{Participation in various agriculture activities-}

More number of farm women was found to participation in agricultural operations i.e. 49.17 per cent followed by medium participation with 30.00 per cent and low participation of 20.83 per cent. Also found higher participation of farm women in agricultural activities. Further data revealed that the farm activities in which farm women obtained the highest score at high level of participation were winnowing process, followed by manure and fertilizers application, harvesting, pest and disease management, irrigation management, seed processing, seed treatment, marketing, collection of harvested crops, soil testing, storage, selection of variety, weeding, field preparation and sowing method.

\section{References}

[1]. Chayal, K.; Dhaka, B. L.; Poonia, M. K.; Tyagi, S. V. S. and Verma, S. R. (2013). Involvement of farm women in decision making in agriculture. Stud Home Com Sci, 7(1):35 37.

[2]. Chouhan, N.M. (2014). Involvement of tribal farm women indecision making, Indian Research J Extension Edu 2: 172-174.

[3]. Dudi and Meena, M.L. (2017). Participation and decision making pattern of farm women in agriculture Asian Journal of Home Science 12 (1): 109-113.

[4]. Godara and Varsha (2017). Analysis of rural women participation in decision making in agriculture sector and factors affectingit: A case study of jind district.

[5]. Patel, S.J.; Kumar, R.; Patel, A.S.; Patel, N.R. and Parmar V. N. (2017). Involvement of Farm Women in Decision making Regarding Dairy Farming in Junagadh District of Gujarat State Indian Journal of Hill Farming., 30(1): 45-58. 